\title{
オーステナイトステンレス鋼の応力腐食について
}

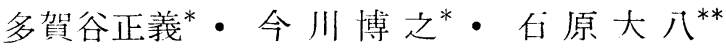

\section{The Stress-Corrosion of Austenitic Stainless Steels}

Masayoshi TAGAYA*, Hiroshi IMAGAWA* and Daihachi ISHIHARA**

We investigated the influence of cold drawing, heat treatment, presence of oxidizing agents and cathodic protection on the susceptibility to stress corrosion of austenitic stainless steel wires. As the corrosive solution, boiling $42 \% \mathrm{MgCl}_{2}$ solution $\left(154^{\circ} \mathrm{C}\right)$ was used in this test. The specimens were stressed in tention and measured the time to fracture. The results are as follows:

1) Influence of cold drawing; When $70 \%$ of the $0.2 \%$ proof stress are applied, the life to failure of stainless steel wires $(0.5 \mathrm{~mm})$ decreases with the increase in degree of cold working up to $20 \%$ reduction, then increases with the increase in degree of cold working up to $40 \%$ or $95 \%$ redustion.

2) Effect of heat treatment; The specimens cooled rapidly after heating at $900^{\circ} \mathrm{C}$ in cracked $\mathrm{NH}_{3}$ gas atmosphere or $1000^{\circ} \mathrm{C}$ in air, were relatively immune from susceptibility to stress corrosion, but the specimens cooled rapidly after heating at $1150^{\circ} \mathrm{C}$ in cracked $\mathrm{NH}_{3}$ atmosphere, became remarkably susceptibile to stress corrosion. The times to fracture by stress corrosion of specimens annealed for one hour at $380^{\circ} \mathrm{C}$ after cold drawing were shorter than those of "as-cold drawn" specimens. The cold drawn specimens annealed at $650^{\circ} \mathrm{C}$ for 1.5 hours showed chromium carbide precipitation, but these specimens showed an improvement in stress corrosion resistance because of the stress relief by those heat treatment.

3) Effect of oxidizing agent; When a small quantity of $\mathrm{KNO}_{3}$ as oxidizing agent was added to the corrosive solution, the fracture of these wires by stress corrosion did not occur.

4) Effect of cathodic protection; The cathodically protected specimens did not fail for 24 hours in the corrosive solution, when the current density exceeded $30 \mu \mathrm{A} / \mathrm{cm}^{2}$. The unprotected specimens failed within one hour.

\section{1. 緒 論}

最近化学巨業のいちじるしい発屡に伴いステンレス銅 の需要も急激に增加し，とくにオーステナイト系のステ ンレス鋼は他のフェライトやマルテンサイト系のものと 比較して耐食性がすぐれているために現在広く化学機悈 に使用されている。ところがこのオーステナイト系のス テンレス鋼は，今までの経験によると応力腐食割レ発生 による破壊を招いており，とくにいちじるしいのは塩素 イオンの存在すると思われる環境で使用される場合で, 中には数力月と言了短期間で破壊を起した例もCopson と (heng') により報告されている。その他応力腐食を 起した環境には硫酸溶液, 石油, 海水, ミカン水, 水道 水, 塭化カルシウム溶液, 沸騰水, などがあげられて (る2)。かかる応力腐食の原因は Dix の電気化学説,
Evans の保護皮膜破㙥説，Weber のヒズミ析出説や Keating の機械的破壊説など3) あっていずれも否定で きない特長や類似点を有して，いまな㹉因追求のため 多くの研究が行なわれている。

一方応力腐食割レを防止するための完全な対策はいま だ見出されていないが，熱処理や腐食抑制凨の添加，陰 检防食法が考光られている。中でも除極防食法は有望の よ5に思われる。曾通オーステナイトステンレス鋼は冷 間加亡あるいは溶接したのちに焼ナマシし，オーステナ イトを安定化して使用するが，この焼ナマシ作業は高温 で行なわれるためにいろいろと困難が生ずる。パイプや 線材などの工業的焼ナマシ法は高温の不活性ガス雾囲気 中で連続的に材料を通過させて短時間で行なわれる。そ こで著者らは冷問引抜した $0.5 \mathrm{~mm} \phi$ のステンレス鋼線 をいろいろな温度で短時間焼ナマシし， $42 \% \mathrm{MgCl}_{2}$ 沸
* 大阪大学工学部（大阪市都島区東野田）

** 日本精線株式会社（大阪市北区梅田）
Osaka Univ. Faculty of Eng.

Nippon Stainless Steel Wire MFG: Co., Ltd. 
第 1 表各種試料の化学組成と引張り強サ

\begin{tabular}{c|c|c|c|c|c|c|c|c|c|c}
\multicolumn{1}{c|}{ 規 } & 格 & C & Cr & Ni & Mo & P & S & Si & Mn & $\begin{array}{c}\text { 引张強サ } \\
\mathrm{kg} / \mathrm{mm}^{2}\end{array}$ \\
J I S & A I S I & & & & & & & & & \\
SUS 8 & $304 \mathrm{~L}$ & 0.03 & 18.73 & 10.74 & - & 0.018 & 0.018 & 0.42 & 1.04 & 75.5 \\
SUS 7 & 304 & 0.07 & 19.05 & 8.75 & - & 0.026 & 0.012 & 0.48 & 1.16 & 82.6 \\
SUS16 & $316 \mathrm{~L}$ & 0.021 & 19.74 & 12.37 & 2.45 & 0.014 & 0.020 & 0.30 & 1.92 & 67.8 \\
SUS15 & 316 & 0.06 & 17.47 & 11.90 & 2.56 & 0.019 & 0.016 & 0.63 & 1.94 & 75.0 \\
SUS 5 & 301 & 0.08 & 17.14 & 7.38 & - & 0.027 & 0.019 & 0.52 & 1.87 & 83.0
\end{tabular}

SUS5 は $0.6 \mathrm{~mm} \phi$ 他は $0.5 \mathrm{~mm} \phi$

第 2 表 加工度の異なる試料の化学組成と諸性質

\begin{tabular}{|c|c|c|c|c|c|c|c|c|c|c|}
\hline $\mathrm{J}$ I S & $\begin{array}{c}\text { 格 } \\
\text { A I S I }\end{array}$ & C & $\mathrm{Cr}$ & $\mathrm{Ni}$ & Mo & $\mathrm{P}$ & $\mathrm{S}$ & \multicolumn{2}{|c|}{$\mathrm{Si}$} & $\mathrm{Mn}$ \\
\hline SUS 7 & 303 & 0.06 & 18.97 & 8.99 & 0.23 & 0.024 & 0.01 & \multicolumn{2}{|c|}{0.55} & 0.95 \\
\hline \multicolumn{2}{|c|}{ 加工度 $\%$} & $\begin{array}{l}\text { 引張 } \\
\mathrm{kg} /\end{array}$ & $\begin{array}{l}\text { リ強サ } \\
\mathrm{mm^{2 }}\end{array}$ & \multicolumn{4}{|c|}{$\begin{array}{c}0.2 \% \text { Proof Stress } \\
\mathrm{kg} / \mathrm{mm}^{2}\end{array}$} & \multicolumn{3}{|c|}{ 透 磁 率 } \\
\hline \multicolumn{2}{|c|}{$1150^{\circ} \mathrm{C}$ 焼ナマシ } & & 73 & \multicolumn{4}{|c|}{28} & \multicolumn{3}{|c|}{1.05} \\
\hline \multicolumn{2}{|r|}{10} & & 94 & & \multicolumn{3}{|c|}{61} & \multicolumn{3}{|c|}{1.07} \\
\hline & 20 & & 104 & & \multicolumn{3}{|c|}{68} & \multicolumn{3}{|c|}{1.36} \\
\hline & 40 & & 140 & \multicolumn{4}{|c|}{82} & \multicolumn{3}{|c|}{2.03} \\
\hline & 60 & & 169 & \multicolumn{4}{|c|}{102} & \multicolumn{3}{|c|}{4.16} \\
\hline & 80 & & 183 & \multicolumn{4}{|c|}{117} & \multicolumn{3}{|c|}{8.71} \\
\hline & 95 & & 243 & & & & & \multicolumn{3}{|c|}{15.25} \\
\hline
\end{tabular}

方法もある。単純引張り応力を付加する場合 は応力が全体的に均一にかかり，またその絶 対量も算出できる利点を有しているが，腐食 の進行によってその部分の断面積は減少する ために, 単位面積当りの作用応力は増加して 破壞を促進するので, 实際の寿命は测定不可 能であると言う欠点がある。一方ではこれが 奏験結果を早めるために研究室で多く採用さ れている。

第 1 図に示したように引張リ応力はテコ方 式を用いて破断までの時間を測定した。一方 陰極防食を行なら場合は, 図には記入しなか ったが陽極として銀線 $(0.5 \mathrm{~mm} \phi)$ を直径

騰溶液 $\left(154^{\circ} \mathrm{C}\right)$ 中でその応力腐食感受性を調べた。さら に冷間引抜加工度と応力腐食感受性の関係や酸化剂添加 の影響, 陰極防食の効果などについて研究した結果を報 告する。

\section{2. 実 験 試 料}

まず最初に応力腐食感受性を比較するために第 1 表に 示す 4 種類の試料を選んだ。さらに冷間加工度と応力腐 食感受性を調べるため第 2 表に示すよ5に同一化学組成 の線径 $0.5 \mathrm{~mm}$ の線で加工度の異なる 7 種を選んだ。な お第 1 表の試料は会社の現場から採取したなまの状態で $1150^{\circ} \mathrm{C} \mathrm{NH}_{3}$ ガス中で短時間連続焼ナマシしたものであ る。

\section{3. 実 験 方 法}

応力腐食試験方法も数多く報告されているが5)，実験 室で短時間に行なら方法として広く使用されているのは 試料に直接引張り応力を付加して破断までの時間を测定 するのがあり，筆者の実験もこの方式を採用し，Hoar と Hines ${ }^{4}$ の装置を改良した第 1 図のよ5な実験装置で 行なった。

その他の試験方法に一定のヒズミを起すまで応力を付 加した状態（たとえば一定の力向に試片を曲げたりまた は引張ったりする）で割レの起るまでの時間を測定する
$20 \mathrm{~mm} \phi$ のラセン状に巻き, その中心に陰極としての試 片がくるように装置して, 試片への流入電流密度を調整 した。さらに試片の単極電位を測定するため 1-N カロ メル電極を第 1 図に示したように配置し

$$
\begin{aligned}
& \text { 試片 } / \begin{array}{c}
42 \% \mathrm{MgCl}_{2} / \text { 飽和 } \mathrm{MgCl}_{2} / \mathrm{N}-\mathrm{MgCl}_{2} \\
1544^{\circ} \mathrm{C}
\end{array} 20^{\circ} \mathrm{C} / \frac{{ }^{\circ} \mathrm{C}}{154 \sim 2} \\
& / \underset{20^{\circ} \mathrm{C}}{N-\mathrm{KCl}} \underset{\mathrm{Hg}_{2} \mathrm{Cl}_{2}}{N-\mathrm{KCl}} / \mathrm{Hg}
\end{aligned}
$$

の電池を構成して测定した。

腐食液としてはステンレス鋼の応力腐食の䂺究に広く 使用されている $42 \%$ 㙞化マグネシウム沸㥢溶液 $\left(154^{\circ} \mathrm{C}\right)$ を使用し，なお液は絶えず一定状態で沸騰するように炉 の盜度を調節するようにした。また長時間奏験を続ける といくぶん沸点が上㫒して くるので上部のガラスコッ クをはずして第 1 図のよう に温度㖕を插入して絶えず

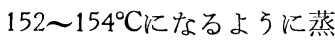
留水を添加し液温を調節し た。腐食液は約 $12 \mathrm{hr}$ 使用 し新しい液に変えるように した。この際 $\mathrm{MgCl}_{2} \cdot 6 \mathrm{H}_{2} \mathrm{O}$ をビーカーに入れて蒸留水 で薄め約 1〜2 hr 沸騰させ

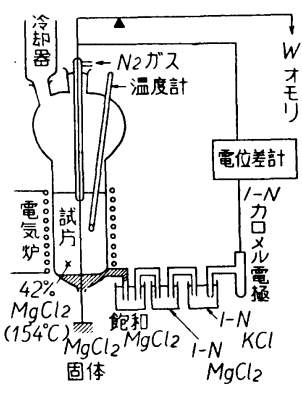

第 1 図 実験装置 
たのち沸点を $154^{\circ} \mathrm{C}$ に調節し，ただちに装置中に流しこ み液の沸騰を見て応力を付加し，同時に時間を記録す る。装置は予熱してあるのでこの間約 $5 \mathrm{~min}$ 以内であ る。 $\mathrm{MgCl}_{2} \cdot 6 \mathrm{H}_{2} \mathrm{O}$ を溶解するとき急熱すると加水分解を 起して $\mathrm{HCl}$ を生成する場合があり液は黄色みを带びる。 この場合前述のよ $5 に 1 〜 2 \mathrm{hr}$ 沸騰させると退色透明に なる。この黄色みを帯びた液を使用すると破断までの時 間を短縮する傾向があり，この点注意を要する。

試片は長サ $60 \mathrm{~cm}$ に切り上下は各々チャックではさみ， 液面の空気ならびに振動などによる局部侵食を避けるた めに試片は液面下 $1.5 \mathrm{~cm}$ までガラス管で覆い, その先 端 $1 \mathrm{~mm} \phi$ の穴から $\mathrm{N}_{2}$ ガスを毎分 20 泡放出させて保 護した。したがって試片が直接溶液に接する部分は下端 の固体状 $\mathrm{MgCl}_{2}$ まで約 $10 \mathrm{~cm}$ である。実験試片の表面 はアンモニアガス中で熱処理したため光沢に富み, スケ ールは無いので軽くペーパーで研摩し, エーテルで脱脂 後使用した。表面を研摩すると応力腐食を受け難くなる と言弓報告もあるが6), これは付加応力が小さい場合で， 本実験のように 0.2\% Proof Stress の約 70\% 以上の 応力を付加した場合は，ほとんど影響は見られなかった。

\section{4. 実験結果と考察}

\section{4-1 各種材料の比較}

第 1 表に示した 5 種の試料について 付加応力 $20 \mathrm{~kg} /$ $\mathrm{mm}^{2}$ のもとで $42 \% \mathrm{MgCl}_{2}$ 沸騰溶液中での応力腐食感 受性を比較して示したのが第 3 表である。

炭素量が比較的高く Ni 量の少ないSUS 7 (304) が一 番応力腐食を起しやすく, Mo 入りの SUS 16 (316L) は低炭素, 高 Ni Kもかかわらずむしろ低炭素の SUS 8 (304 L) より少っている。中でもとくにいちじるしいの は SUS 5 (301) : $17 \mathrm{Cr}-7 \mathrm{Ni}$ の $\alpha+\gamma$ 型のものは他の ものに比べて良い耐応力腐食性を示した。

\section{4-2 冷間加工の影響}

試料は第 2 表に示した同一組成の材料に打いて，各々 加工度の異なる直径 $0.5 \mathrm{~mm}$ の線 を使用した。一定付加応力 $25 \mathrm{~kg} /$

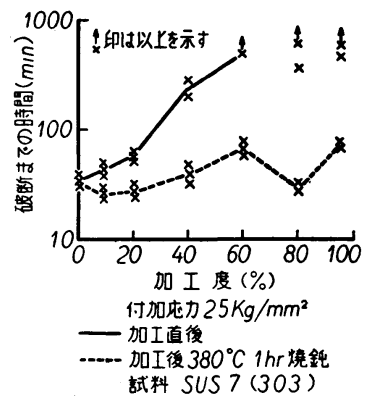

第 2 図 加工度と忘力腐食の関係
第 3 表 各種材料の忍力腐食感受性

\begin{tabular}{cr|rrrrr|r} 
規 & 格 & \multicolumn{2}{|c|}{ 破断までの時間 } & $(\mathrm{min})$ & 平 & 均 \\
J I & S & & & & & & \\
S U S & 8 & 93 & 81 & 78 & 89 & 85 & 85 \\
S U S & 7 & 25 & 23 & 20 & 23 & 19 & 22 \\
S U S & 16 & 50 & 58 & 40 & 65 & 52 & 50 \\
S U S & 15 & 65 & 70 & 45 & 60 & 72 & 62 \\
S U S & 5 & 147 & 97 & 120 & & & 121 \\
\hline
\end{tabular}

付加応力 $20 \mathrm{~kg} / \mathrm{mm}^{2}$

$\mathrm{mm}^{2}$ を与えた場合の破断までの時間と加工度の関係を 第2 図にまた各試料の $0.2 \%$ Proof Stress を测定し 号の $70 \%$ の応力を与えた場合の結果を第3図に示す。

一定付加応力の場合には加工度の増加とともに応力腐 食寿命も延びている。これは単純引張り応力を付加する 方式を採用したことと, 加工度の増加とともに引張り強 サが增加するため, 割レが進行して破断を導くには, 引張 リ強サの大きい材料はど割レも多く進行せねばならない からそれだけ破断までの時間も長くなる。そこで降伏点 以下で各試料とも等しい変形量を生じる荷重の下で比較 した結果が上述の第 3 図で,加工度 $20 \%$ 付近に最も侵さ れやすい現象がある。これは冷間引抜した場合のステン レス鋼線の表面部と, 内部に存在する方向の異なる残留 応力に起因するためで, 中間の加工度のときがこの残留 応力が一番大きく，たとえば黄銅の場合を例にとると7), $20 \%$ 付近で長サ方向の残留応力が大きく，60\% 以上に なるとほとんど消失している。この残留応力は線の表面 では引張リ応力であるため，これと外部引張り付加応力 との相互作用によって, 最も応力腐食を起しやすくなっ たと考える。試片が細いため残留応力の测定はできなか った。一方顕微鏡観察によると，加工度 20\%までは結 晶粒の原形を一部变形しながらも残しているが，加工 度40\% 以上になると結晶粒は中心部もすべて引抜方向 に伸ばされている。

\section{4-3 熱処理の影響.}

試料は第 2 表の SUS 7 (303) と第 1 表 の SUS 5 (301) を使用し, 第 4 表に示す 種々の熱処理を行なってて各種付加応力を与 えた場合の破断までの時間を測定した。こ の表を参考に，a）焼ナマシ温度の影響, b) $650^{\circ} \mathrm{C}$ 炭化物析出の影響, c) 低温焼ナ マシ效果について述べる。

a) $1150^{\circ} \mathrm{C}$ から急冷したものは，付加応 力 $20 \mathrm{~kg} / \mathrm{mm}^{2}$ の下で $1 \mathrm{hr}$ 内外で破断す るのに対して, $1000^{\circ} \mathrm{C}$ から空気中徐冷また は水冷および $900^{\circ} \mathrm{C}$ から $\mathrm{NH}_{3}$ ガス中急冷 したものは同じ付加応力 $20 \mathrm{~kg} / \mathrm{mm}^{2}$ の下で $10 \mathrm{hr}$ 以上も耐之, 付加応力を $33 \mathrm{~kg} / \mathrm{mm}^{2}$ 


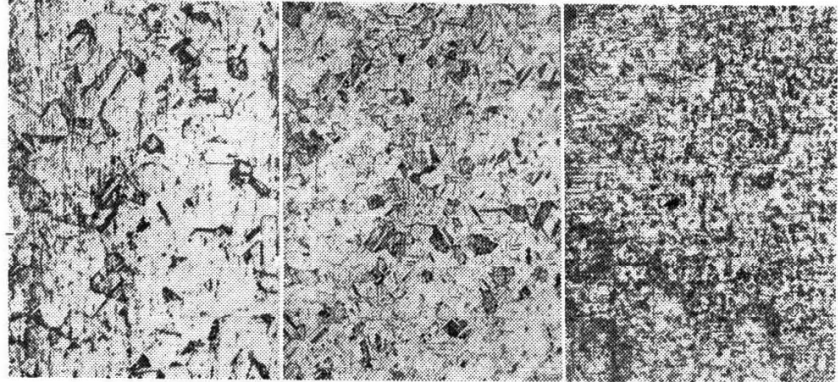

$1150^{\circ} \mathrm{C} 40 \mathrm{sec}$ 焼ナマシ $\times 150(\times 2 / 3)$ $1000^{\circ} \mathrm{C} 5 \mathrm{~min}$ 焼ナマシ $\times 150(\times 2 / 3)$ $900^{\circ} \mathrm{C} 40 \mathrm{sec}$ 烧ナマシ $\times 200(\times 2 / 3)$

写真 1 SUS 7 の頙徽鏡組織 （濃塭酸エッチ）

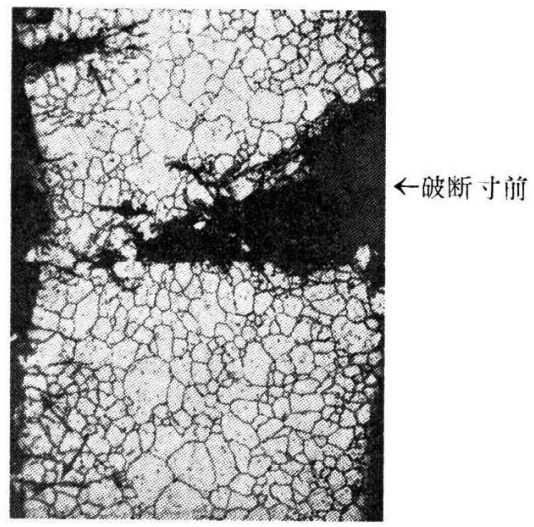

写真2 $1150^{\circ} \mathrm{C}$ 焼ナマシ後 $650^{\circ} \mathrm{C} て ゙ 1.5 \mathrm{hr}$ 加熱 L たSUS 7 の応力腐食割レ，10\%シュウ酸で 電解エッチ $\times 150(\times 1 / 2)$

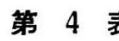

熱处

\begin{tabular}{|c|c|c|}
\hline \multirow{2}{*}{ No } & 規 & 格 \\
\hline & J I S & A I S I \\
\hline 1 & SUS 7 & 303 \\
\hline 2 & " & " \\
\hline 3 & " & " \\
\hline 4 & " & " \\
\hline 5 & " & " \\
\hline 6 & " & " \\
\hline 7 & " & " \\
\hline 8 & " & " \\
\hline 9 & " & " \\
\hline 10 & " & " \\
\hline 11 & " & " \\
\hline 12 & " & " \\
\hline 13 & SUS 5 & 301 \\
\hline 14 & " & " \\
\hline 15 & " & " \\
\hline
\end{tabular}

\section{理}

$$
\begin{aligned}
& \text { 焼ナマシ線 } * \\
& \text { 同上を } 650^{\circ} \mathrm{C} 1.5 \mathrm{hr} \\
& 20 \% \text { 冷間引拔 }
\end{aligned}
$$

同 上

$20 \%$ 冷間引拔後 $380^{\circ} \mathrm{C} 1 \mathrm{hr}$

$20 \%$ 冷間引拔後 $650^{\circ} \mathrm{C} 1.5 \mathrm{hr}$

$900^{\circ} \mathrm{C} \rightarrow \mathrm{NH}_{3}$ ガス中急冷 †

同上

$1000^{\circ} \mathrm{C} \rightarrow$ 空気中徐冷

$1000^{\circ} \mathrm{C} \rightarrow$ 水冷

$1150^{\circ} \mathrm{C} \rightarrow \mathrm{NH}_{3}$ ガス中急冷†

No. 7 を $650^{\circ} \mathrm{C} 2 \mathrm{hr}$

$75 \%$ 冷間引拢

$900^{\circ} \mathrm{C} \rightarrow \mathrm{NH}_{3}$ ガス中急冷

\begin{tabular}{|c|c|c|c|c|c|}
\hline $\begin{array}{l}\text { 付加応力 } \\
\mathrm{kg} / \mathrm{mm}^{2}\end{array}$ & $\begin{array}{l}0.2 \% \text { Proof } \\
\text { Stress } \\
\text { 火対する割合 }(\%)\end{array}$ & 破 & $\frac{\text { 断 ま }}{(\min )}$ & の時 & $\begin{array}{l}\text { 間 } \\
\text { 平 均 }\end{array}$ \\
\hline 20 & 70 & 35 & 48 & 43 & 42 \\
\hline 25 & 90 & 84 & 86 & & 85 \\
\hline 25 & 40 & 59 & 61 & 53 & 57 \\
\hline 48 & 70 & 22 & 24 & 15 & 20 \\
\hline 25 & 40 & 26 & 26 & & \\
\hline 46 & 70 & 115 & 101 & & 108 \\
\hline 20 & 70 & $>600$ & $>600$ & & $>600$ \\
\hline 33 & 120 & 229 & 257 & & 243 \\
\hline 33 & 120 & 208 & 228 & & 218 \\
\hline 33 & 120 & 221 & 249 & & 235 \\
\hline 20 & 70 & 55 & 84 & 68 & 69 \\
\hline 33 & 120 & 205 & 197 & & 201 \\
\hline 25 & & 206 & 228 & & 217 \\
\hline 33 & 120 & 405 & 416 & & 410 \\
\hline 20 & 70 & 147 & 97 & 120 & 121 \\
\hline
\end{tabular}

$1150^{\circ} \mathrm{C} \rightarrow \mathrm{NH}_{3}$ ガス中急冷
处理.の影響

飞增加してもな打 $4 \mathrm{hr}$ 近く耐兄, $1150^{\circ} \mathrm{C}^{\circ}$ の 熱処理の場合と比較にならない耐応力腐食性 を示した。したがって $1150^{\circ} \mathrm{C}$ 以上の焼ナマ シは好ましくないと言える。この原因追求の ため,まず試片の顕微鏡組織を観察した。 $900^{\circ} \mathrm{C}$ で短時間燒ナマシした試料の組織は非 常に細かい結晶粒からなって完全に再結晶を 起している。 $1000^{\circ} \mathrm{C} に 5 \mathrm{~min}$ 保持し水冷し た試料と $1150^{\circ} \mathrm{C}$ 短時間焼ナマシした試料は いずれも再結晶を完了し $1150^{\circ} \mathrm{C}$ 焼ナマシの 場合がいくぶん結晶粒が成長しているだけで あまりいちじるしい差は無い。したがって次 の実験を行なった。

$\mathrm{Fe}-\mathrm{Cr}-\mathrm{Ni}$ の状態図 ${ }^{87}$ からもわかる上5に, $1150^{\circ} \mathrm{C} て ゙$ は $\alpha+\gamma$ の領域に入るから, この場合み当然 $\alpha$ が出现 していると考えられる。これを確認するため磁父测定を 陚みた。それにはケン引法で化学天ビンを改良, さらに レンズで拆大して磁化の強サ, すなわち $\alpha$ の相対量を比 較したところ, $900^{\circ} \mathrm{C}$ 熱処理の場合を 1 とすれば $1150^{\circ} \mathrm{C}$ の場合 1.3 となり, $1150^{\circ} \mathrm{C}$ の方が $\alpha$ の量が多いことが わかった。この比は SUS 5, SUS7, いずれの陚料も大 体等しい值を示した。以上の上らな $\alpha$ の出現により $\mathrm{Cr}$ 濃度に差を生じ, 局部電池を構成して応力腐食を助長す ると考える。その他の原因として，一部焼入レによる熱 応力も考兄られる。

b) 冷間加工後 $650^{\circ} \mathrm{C} て ゙ 1.5 \mathrm{hr}$ 加熱すると, 专しろ寿 命はかなり伸び，炭化物析出に上る恵影響よりも焼ナマ

†会社で $\mathrm{NH}_{3}$ ガス中にて熱処理

* 会社から狫ナマシ線としてもらったまま 
シ効果が打ち勝って良好な結果を現わす。そこで炭化物 の析出の影響のみを見るため $900^{\circ} \mathrm{C} て ゙$ 焼ナマシ後 $650^{\circ} \mathrm{C}$ で $2 \mathrm{hr}$ 加熱して試験を行なったが，寿命の短縮程度は ごくわずかで炭化物が完全に析出してしまった状態にな れば，ほとんど㐫力腐食に対して悪影響をおよぼさない のである。しかし一般に使用される場合には炭化物析出 による粒界腐食は当然起るのであるから，この点は考虑 しなければならない。

c） $380^{\circ} \mathrm{C}$ での低温焼ナマシを行なった場合は第 2 図 の点線で示したように，加工度に関係なく同一付加応力 下で $1 \mathrm{hr}$ 内外で破断する。一方このことは同一変形荷 重の下では当然加工度の增加につれ，いちじるしく応力 腐食を起しやすいことを意味する。この原因は $\alpha$ や炭化 物の析出により結晶粒にヒズミを生じたからである。事 実 60\% 加工した材料の透磁率を比較して見ると，加工 後 4.1 が $380^{\circ} \mathrm{C}$ 焼ナマシ後 4.9 に増加し $\alpha$ の析出を示し ててた。一方顕微鏡組織では加工によって長く王延方向 に伸びた結晶粒には倍率 200 倍の下でほとんど変化は見 られないが，以上のよ5に析出硬化により結晶格子のヒ ズミを生じ, 応力腐食の感受性が大となったものと考光 られる。

\section{4-4 酸化剂添加の影響}

酸化剤の添加は局部電池の減極作用によって腐食を促 進する働さをする一方，金属表面に強固な酸化皮膜を生 成させて防食効果を現わすとも考兄られる。応力腐食に 対してもこれがどのような作用をするかを見るために， クロム酸, 硝酸カリ, 過マンガン酸カリなどの酸化剤を 添加してその効果を調べた。 $42 \% \mathrm{MgCl}_{2}$ 溶液 $400 \mathrm{cc}$ に 対し 0.1〜10 g を加完応力腐食寿命に及ぼす影響の結果 を第 4 図に示す。使用した試料はいずれも SUS 7 (303) を用いた。クロム酸は少量の添加で急激に応力腐食を助 長するようになり，1 $\mathrm{g}$ 以上の添加はあまり影響は見ら れない。さらに $10 \mathrm{~g}$ クロム酸を添加したときは $8 \mathrm{~min}$ にまで寿命が短縮される。これは $\mathrm{CrO}_{3}$ が強酸化剤であ るため $\mathrm{MgCl}_{2} \cdot 6 \mathrm{H}_{2} \mathrm{O}$ の解離を促進し， $\mathrm{HCl}$ を生成する ため金属表面の保護皮膜が侵されることに起杏すと思

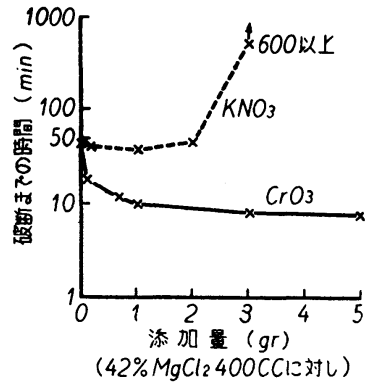

- 試料 SUS 7 (303)

第 4 図 酸化剂添加の影響

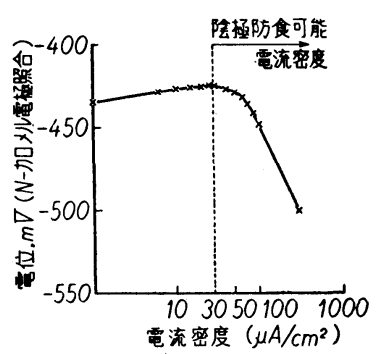

第 5 図防食電流密度と電位の関係
ラ。事実いちじるしく壏素の臭いがする。一方硝酸カリ は $1 \mathrm{~g}$ 添加付近で少し応力腐食を起しやすいが，これ以 上添加すると次第にその効果を現わし， $3 \mathrm{~g}$ 以上添加す ると $10 \mathrm{hr}$ 以上の寿命を示し急に防食効果を現わす。ま た過マンガン酸カリはクロム酸と同じ傾向を示す。した がって $\mathrm{KNO}_{3}$ は防食効果を現わし, $\mathrm{CrO}_{3}$ と $\mathrm{KMnO}_{4}$ は 防食効果を示さず, 反対に応力腐食感受性を大とする。

\section{4-5 陰極防食の効果}

応力腐食の機構は主として電気化学的方面からいろい ろと研究されている ${ }^{9)}$ 点から見て，院桠防食によって応 力腐食を避けようとすることも当然考えるべきである。 まず適当な防食電流密度を求めるために陰極分極曲線を 求めた。前述のように陽極として 銀線を用い, SUS 7 (303)の試料を陰極としてその流入電流密度を変化させ, 陰極の電位を測定した。電流密度は一定時間 $10 \mathrm{~min}$ 毎 に増加させて第 5 図の分極曲線を得だ。

電流密度 $30 \mu \mathrm{A} / \mathrm{cm}^{2}$ 近くになると陰極の電位は卑に なり始め，ここに拈いて防食の効果が現われてくる。こ のときの電位は $1-N$ カロメル電極に対して $-425 \mathrm{mV}$ を示す。これを参考とし実際 $42 \% \mathrm{MgCl}_{2}$ (154 $\mathrm{C}$ ) 中 での陰極防食の効果を見るため 20，25，27，30，35， $40 \mu \mathrm{A} / \mathrm{cm}^{2}$ の各防食電流密度の下で連続 $24 \mathrm{hr}$ 腐食試験 を行なった結果は第 6 図に示すと拈りである。

防食電流を通じないときは付加応力 $20 \mathrm{~kg} / \mathrm{mm}^{2}$ の下 で平均 $42 \mathrm{~min}$ で破断したものが $20 〜 27 \mu \mathrm{A} / \mathrm{cm}^{2}$ と電 流密度の増加とともに寿命も急激に延びている。さらに $30 \sim 40 \mu \mathrm{A} / \mathrm{cm}^{2}$ になると完全に防食効果を示し $24 \mathrm{hr}$ 後 でも破断しない。な抗この試料の引張り強サを比較した が試験後の低下は見られない。一方防食電位もー $420 \mathrm{mV}$ 以下に保持すればよいことが判る。さらに防食電流密度 を $500 \mu \mathrm{A} / \mathrm{cm}^{2}$ まで上年させ，水素ガス発生状態で試験 したところ, 同様に $24 \mathrm{hr}$ 以上耐え $24 \mathrm{hr}$ 後の引張り強サ もほとんど減少なく，ただ水素ゼイ性により伸ビが $50 \%$ から $25 \%$ に滅少していた。第 6 図に拈いて電流密度 $27 \mu \mathrm{A} / \mathrm{cm}^{2}$ 以下の場合には最初から電位は少しずつ上年 するが，これは Hoar と Hines ${ }^{10)}$ の得た曲線と大体一 致している。 $30 \mu \mathrm{A} / \mathrm{cm}^{2}$ 以上になると最初 $20 \sim 30 \mathrm{~min}$ 
間ぐらいかなり電位は上畀し，このときに分掼現象を起 し表面にち密で安定な皮膜を生成すると推察される。こ れ以後は防食電流密度の增加につれ, 上り卑になる時間 も長く, $40 \mu \mathrm{A} / \mathrm{cm}^{2}$ の場合約 $10 \mathrm{hr}$ 近く徐々に電位は 下っている。それ以後は汪とんど変化は見られず $24 \mathrm{hr}$ 後には少し電位が上升していた。これは陽極に銀を使用 したので夜中に塩化銀が生成したためと考えられる。

\section{5. 結 論}

今日ステンレス鋼の応力腐食による事故が数多く見ら れている折から数種のステンレス鋼線の $42 \% \mathrm{MgCl}_{2}$ 中 に打ける応力腐食感受性や加工度, 熱処理の影響, 腐食 液中に酸化剂を添加して金属の表面に保護皮膜を生成せ しめることによる応力腐食防止法および除極防食法につ いて検討した。

[1] SUS 8, SUS 7, SUS 16, SUS 15, SUS 5 の 5 種 を $1150^{\circ} \mathrm{C}$ 飞短時間加熱焼入レこた場合の応力度食感受 性を比較すると SUS 7 が最も大で, Mo 入りの SUS 15, SUS 16 がそれに次いでいる。SUS 16 は SUS 8 より応 力腐食感受性が大で, Mo 入りの場合は低炭素とい5影 響は見られなかった。中でもSUS８はかなり寿命が長 く, SUS 5 になると他の材料より一段と応力腐食を起し 難くなる。

[2] 冷間加工後 0.2\% Proof Stress の 70\% の応力 を付加した場合の寿命を比較すると, 加工度 20\% まで はその増加と共に応力腐食を起しやすく，さらに $40 \%$ 以上の加工度になると, 加工度の増加とともに応力腐食 を起し難くなる。しかし 900〜 $1000^{\circ} \mathrm{C} て ゙$ 焼ナマシした場 合が非常に良い耐応力腐食性を示し, 加工度の增加によ る影響とは比較にならない。約 $20 \%$ の加工度では, 線 の外表部に存在する引張り残留応力と付加応力の相互作 用により応力腐食を最も起しやすい。

〔3〕 $900 \sim 1000^{\circ} \mathrm{C}$ で焼ナマシした場合に応力腐食感受 性が最少となるが， $1150^{\circ} \mathrm{C}$ で焼ナマシした場合は一部 $\gamma$ が $\alpha$ に変態するため $\mathrm{Cr}$ 濃度の差を生じ, 応力腐食を 助長し破断をいちじるしく早める。 $650^{\circ} \mathrm{C}$ で焼ナマシし

(10賁よりつづく)

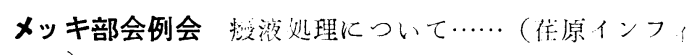
ルコ)

挨拶…‥リリアム・ホルト（ユージライト），映㷙上映 表面硬化研究会 急述於熱に上る結晶粒度と非金属介在 物の燒割性括よび残留応力に及ぼす影響……本間八郎 (日立製)

パレル仕上研究会 挨拶……鵜飼䉝一（鵜飼技事務所） 业鉛ダイカスト製品のバレル仕上……津田伊三郎 （三井金鈗中央研）バレル仕上のメディアについて ……小林久峰（敷島チプトン）
た場合，炭化物が析出するにもかかわらず焼ナマシの効 果を受け，むしろ寿命が長くなり，割レは結晶粒を貫い ている。一方 $900^{\circ} \mathrm{C}$ で暁ナマシした材料を $650^{\circ} \mathrm{C} て ゙ 2 \mathrm{hr}$ 加熱し炭化物を完全に析出させても，その影響は活とん ど見られない。

[4] $42 \% \mathrm{MgCl}_{2}$ に添加して防j食効果を上げるためのの 酸化剤としては $\mathrm{KNO}_{3}$ を $42 \% \mathrm{MgCl}_{2} 400 \mathrm{cc}$ に対し $3 \mathrm{~g}$ 以上の添加が有効である。なお $\mathrm{CrO}_{3}, \mathrm{KMnO}_{4}$ は反対 に応力腐食を助長する。

[5]本実験で $1 \mathrm{hr}$ 以内で破断した試料が防食電流密 度 $30 \mu \mathrm{A} / \mathrm{cm}^{2}$ 以上を通じて陰極防食をすると $24 \mathrm{hr}$ 以上 耐え, その効果が顕著である。電流密度を $500 \mu \mathrm{A} / \mathrm{cm}^{2}$ に 増して水素発生状態に扮いてもやはり $24 \mathrm{hr}$ 以上耐える が当然水素ゼイ性が起る。（本論文の一部は 33 年 11 月 21 日本大会で, また他の一部は 34 年 4 月 日本金属学会 で発表したものである)

(1959.2.14 受理)

\section{文 献}

(1) H. R. Copson and C. F. Cheng, Corrosion, 13, 397 t (1957)

(2) J. J. Heger, Metal Progress, 67, 109 (1955) March.

（3）山本洋一，金属防食便覽， p. 54, 日刊工業新聞社: (1957)

(4) T. P. Hoar and J. G. Hines, J. Iron Steel Inst., 182, 124 (1956)

(5) Hugh P. Godard and J. J. Harwood, Corrosion, 11, $93 \mathrm{t}$ (1955)

(6) S. E. Hadden and E. C. W. Perryman, Metallurgia, 42, 392 (1950)

（7）加藤正夫㰴，加工冶金学下，p, 324（コロナ社）

(8) C. A. Zapffe, Stainless Steel, p. 136 (1949)

(9) R. B. Mears, R. H. Brown and E. H. Dix, "Symposium on Stress-Corrosion Cracking of Metals" ASTM-AIMME p. 323 (1945)

(10) T. P. Hoar and J. G. Hines, J. Iron \& Steel Inst, 177, 248 (1954)
関西支部講演会 挨拶……所長（兵簐機工指），三木全 物について……横山智代次（兵庫機工指）

関西支部溶射技術講演会 セラミックおよびコルモノイ 系粉末溶射について……时中広占（工. 技院阪工試） 技術講習……ラミック括よびニッケルクロムボロンの 実演ならびに実習。

\section{入会 者}

〔正会員〕中島晕雄, 原勲, 竹崎正勝, 止村止治, 唋 木義昭, 小林栄想, 大谷俊雄, 園部太郎, 田代政夫, 渡 辺誹利, 势原友宣, 榎本斦闰, 青木重雄 